\title{
Albanon
}

Revistë kulturore

\section{Sa pak i njohim, sa shumë na dhanë}

\author{
Fetah Biza
}

Duke marrë shkas nga festimet e 100 vjetorit të lëvizjes artistike-teatrore në Elbasan, bëmë një retrospektivë për të vlerësuar dhe risjellë në memorien e qytetit të gjithë ata emra që e ngritën lart nivelin artistik të Elbasanit. Njëri prej tyre është Mustafa Curri, për të cilin pak flitet, pak dihet e pak evidentohet.

\section{Cili ishte Mustafa Curri?}

Mustafai ishte i biri i Haxhi Currit, me origjinë nga Gjakova. Familja e tij, pra ajo e Currajve mbahej në Gjakovë e më gjërë, si një nga familjet më patriote të kombit. Pasi kishte përfunduar studimet në Turqi, Haxhi Curri, i ati i Mustafait, u emërua imam në Elbasan. Nga ana e së ëmës, Mustafai kishte lidhje me qytetin e Elbasanit, pikërisht me familjen e madhe Arapi. Shtëpia në lagjen Kala të Elbasanit, u dha mundësinë të krijonin miqësi me të gjitha familjet patriote të kalasë.

Mustafai lindi në vitin 1891. Mësimet e para i mori në shkollën Normale, gjë të cilën e vërteton edhe dokumentacioni i shkollës. Në një regjistër amze të kësaj shkolle, Mustafa Curri figuron me nr. 8, sipas renditjes alfabetike. Mësimet e larta, i kreu në Manastir e në Stamboll dhe pas mbarimit të tyre, kthehet të punojë në Elbasan, fillimisht si mësues në Normale e më pas drejtor i parë i shkollës “Naim Frashëri”. Punën e tij në këto dy institucione të rëndësishme të arsimit mbarëkombëtar, Mustafai nuk e mbylli brenda mureve të shkollës, por i kapërceu ato, duke u angazhuar në grupet e shoqërive patriotike e përparimtare që ishin krijuar në Elbasanin e atyre viteve , siç ishte edhe shoqëria "Aférdita" ku ai aderoi. 
Për krijimin e shoqërive teatrore, mbështetemi në burime të shumta, në revista e gazeta si "Posta e Shqypnis", "Shkodra", ku te kjo e fundit, në një artikull që i dedikohet njërës prej shfaqjeve të dhëna në këtë qytet shkruan: "Pjesët teatrore që dha shoqëria e Elbasanit lanë përshtypje shumë të madhe në popull, amatorët luajtën si me qenë aktorë të vërtetë”.

Është për t'u theksuar fakti, që kjo shoqëri teatrore kishte dhe qëllime bamirësie. Përveç ngritjes së godinës së teatrit dhe dekoracionit të saj, anëtarët e saj donin të ndihmonin të vobektët. Mustafa Curri u ngjit në skenë me dramën e parë "Besa" dhe vazhdoi të aktivizohet më tej si aktor, përthyes, dramaturg dhe regjisor. Nivelin e tij profesionist, e plotësonte edhe më shumë zotërimi i disa gjuhëve të huaja, të cilat e ndihmonin në ngritjen e nivelit artistik të shoqërisë teatrale.

Talenti dhe aftësia, e bënë Mustafa Currin, që ai të spikaste si aktor në dramat:

1. "Besa" e Sami Frashërit, tragjedi me 6 akte, me personazhin e Demir Beut, në rolin e tij si drejtues $i$ shkollës qendrore nga paria e Tepelenës, shfaqje e luajtur vetëm në Shkodër.

2. "Dhëndër me përdhuni”, komedia me një akt, me personazhin e Tasi Plandëzë, në rolin e një tregtari të moshuar e të pasur.

3. "E bija e bankierit", komedia me një akt, me personazhin Vitorija (këtu ai luan rolin e femrës).

4. (Zavalli çuxhuk) "I mjeri djalë", dramë me 3 akte, me personazhin e Halilit në rolin e të atit të Shefikasë.

Si përkthyes ai realizoi:

1. (Zavalli çuxhuk) "I mjeri djalë", dramë e përkthyer me tri akte, (2022 shtator 1918).

2. "Mulla Tahiri" e Namik Qemalit, me një akt dhe 13 skena, (viti 1925).

3. "E mjera vajzë", dramë me 5 akte.

Si dramaturg, pena e tij shkroi dramat: "Fundi i pijes" - monodramë (e shfaqur më 26 dhe 28 shtator 1918), "Vajza Trimëreshë" ose "E mjera vajzë", viti ( 1918), "Mulla Tahiri”, dramë me një akt e 13 tabllo. Ndërsa si regjisor, ai vuri në skenë dramën e përkthyer prej tij "I mjeri djalë", (20-22 shtator

1 organ i botuar në Shkodër (1916-1918) prej Gj. Fishtës 


\section{Albanon}

\section{Revistë kulturore}

1918), "E mjera vajzë", "Fundi i pijes" shfaqur më 26 dhe 28 shtator 1918 dhe "Vajzat trimëreshë" (në vitin 1918).

Veprimtaria e Mustafa Currit është akoma më e gjerë se kaq. Me ardhjen në Elbasan të dy topave të parë të futbollit nga Stambolli, u krijua edhe skuadra e parë e futbollit në qytet. Në këtë kohë, shoqëria "Aférdita" u quajt "shoqëri kulturore, artistike, sportive". Duke marrë spunto nga këto zhvillime, Mustafa Curri angazhohet tani si trajner amator. Ai stërviste të rinjtë e qytetit në fushën buzë Shkumbinit, që njihej nga të gjithë me emrin "Balashja e Beut".

Në vitin 1920, Mustafa Curri shkëputet nga arsimi, arti e sporti, për të hedhur hapa në një fushë të re, atë të politikës. E gjitha filloi kur ai fitoi vendin e parë në një konkurs të organizuar nga Këshilli i Ministrave, si njohës i shumë gjuhëve dhe u dallua për kaligrafi të bukur. Gjatë karierës 16 - 17 vjeçare, që konsiston në periudhën e viteve 1920 - 1937, ai realizoi detyra tepër delikate e shumë të rëndësishme. $U$ emërua si fillim sekretar i Ministrisë së Brendshme, pastaj sekretar dhe kryesekretar në Kryeministri. Në vitin 1928, kalon si sekretar i përgjithshëm në Oborrin Mbretëror.

Gjatë punës dhe vizitave të tij në krye të delegacioneve mbretërore, nga mbretëritë e Europës ai ka marrë një seri dekoratash, si:

1. “Kryqi i oficerit të madh të kurorës së Italisë" - akorduar në vitin 1931, nga Viktor Emanueli I, në pritjen që iu bë delegacionit në pallatin Mbretëror të Savojës.

2. Në vitin 1933, i akordohet një tjetër dekoratë "Shën Sava” nga i dërguari i Mbretërisë së Serbisë, me motivacionin për kontribut të fqinjësisë së mirë midis mbretërive dhe përpjekjeve diplomatike të tij për sheshimin e kontradiktave midis dy vendeve me probleme të ndryshme.

3. Në vitin 1932, iu akordua dekorata "Oficer $i$ madh, $i$ urdhrit të kurorës së Rumanisë".

4. Nderohet me dekoratën e lartë "Grand Ducal de la Cuoronne de Chene" të Luksemburgut, e cila i motivohet "Mik i Dukës e krijuesi i miqësisë së dy vendeve të vogla, Mbretërisë së Shqipërisë dhe Dukatit të Luksemburgut". Këtë dekoratë e ka marrë gjatë kohës që ishte me pushime në Luksemburg dhe bëri një vizitë kortezie te Duka i Madh i Luksenburgut, me ftesë të këtij të fundit.

5. Në vitin 1929, në prani të Këshillit të Ministrave dhe Oborrit Mbretëror, në përvjetorin e ngritjes së flamurit, Mbreti Zog I i 
dorëzoi Mustafa Currit dekoratën më të lartë të Mbretërisë, atë të "Urdhërit të Skënderbeut" (Shqiponjën e Artë) me motivacionin: "Nënpunës shembullor, nacionalist i vendosur, besnik i Mbretërisë".

Mustafa Curri, u nda nga jeta në vitin 1937, pa përjetuar dramën e madhe që shoqëria shqiptare kaloi pas çlirimit. Por nga kjo nuk shpëtoi familja Curri, e cila përjetoi një kalvar të gjerë persekutimesh si: burgosje, internime, sekuestrime shtëpish e pasurish etj.

Këjo dramë âsht luejt tri herë prej shoqënis theatrore t'Elbasanit, prej këtyne njerëzve :

"I mjeri djalë"

\begin{tabular}{|l|l|l|l|}
\hline $\mathrm{Nr}$ & Personazhet & Roli & Aktori që interpreton \\
\hline 1 & Zeqi Beu - & $\begin{array}{l}\text { Djalë 19 vjeç, student në shkollën } \\
\text { mjekse të ushtrisë }\end{array}$ & Etëhem Haxhiademi \\
\hline 2 & Shefikaja - & Një vajzë 14 vjeç, e dashura e Zeqi Beut & Hasan Ceka \\
\hline 3 & Halili - & I jati i Shefikas & Mustafa Curri \\
\hline 4 & Tahireja - & E ëma e Shefikas & Qamil Çela \\
\hline 5 & Sherifeja - & Një grue, komshije e Shefikas & Josif Popa \\
\hline 6 & Xhemilja - & Shërbëtore & Josif Biba \\
\hline 7 & Mjeku- & & Mustafa Sheshaj \\
\hline & \multicolumn{2}{|l|}{ Kopështi letrar, Elbasan, vjesht' e parë, 1918, nr.2. } \\
\hline
\end{tabular}

\section{Rreth temës të dramës.}

"I mjeri djalë", ka tematikë emancipimin e femrës, ngjyrosur artistikisht me nota romantike, ai përshkohet nga kulti i ndjenjës së romantikëve.

\section{Rreth përmbajtjes së dramës.}

Është drama tragjike e dy të dashuruarve të pafat, është sfida e dhimbshme e shpirtit njerëzor. Në qendër është njeriu e mesazhi i emancipimit të tij dhe e çlirimit nga vargojtë e së shkuarës anadollake e obskurantiste; jo me kot vepra ka një fund tragjik, të dy heronjtë e dashuruar Shefikaja dhe Njazi beu vdesin, e para nga një sëmundje e rëndë,lëngatë e dashurisë dhe i dyti vetëhelmohet. Mesazhi është $i$ qartë, duhet luftuar për çlirimin nga vargojtë e së kaluarës sado e rëndë të jetë kjo luftë, edhe nëse ka viktima e sotmja duhet varrosur, e nesërmja do të jetë në favor të një mendësije të re e një shoqërije të re.

\section{Vlerat ideoartistike të dramës.}

Janë notat e romantikëve të mëdhenj botërore si Skot, Hygo, Pushkin, notat e romantikëve shqiptarë si De Rada, Naim Frashëri, përqëndruar në kultin e dashurisë.

Shefikaja, e ndjeshme, e brishtë një lloj Xhuljete, Sharlotë që vuan pafundësisht, që sakrifikon për ndjenjën e saj sublime; Njazi Beu një Verter që e përjeton dashurinë po ashtu dhimbshëm e tragjikisht, janë apostuj të një epoke të re. 


\section{Albanon}

\section{Revistë kulturore}

Emocionaliteti i sinqertë e i fuqishëm, sakrifica për dashurinë pa rebelizëm, përkushtimi, zjarri i pasionit, magjia e transparenca e ndjenjave, mënyra e trishtë e shikimit të botës, pështjellimi psikologjik i heronjve deri në një dhimbje të thellë që justifikohet bukur nga mosha tepër e re, rrethanat sociale, e bëjnë këtë vepër tepër interesante e edukative për kohën.

Konceptet humaniste të veprës e bëjnë autorin Namik Qemal dhe përkthyesin e përshtatësin Mustafa Curri vizionarë, emblematikë të një shoqërie të re antifeudale, të lirë e pa paragjykime.

\section{Rreth vlerave të dramës.}

Megjithëse vepër e përkthyer, Mustafa Curri u mundua që psikologjinë e personazheve ta jepte me transparencë dhe kolor. ndaj. Edhe pse ka kaluar një shekull, na bën përshtypje si tornadoja e ndjesive të heronjve, ekzaltimi, naiviteti, pasioni që pikturojnë çiltër e ëmbël pushtetin e dashurisë, mund të çojë deri në fatalitet.

Gjuha e veprës më tepër bazohet në dialogjet Shefika e Njazi bej, në monologjet e Shefikas dhe nga ndërhyrjet e ndonjë personazhi tjetër si mamaja e Shefikas, babai, doktorri. Leksiku pasqyron botën shpirtërore të personazheve, gjuha artistike e thjeshtë, emocionale, lirikë e dialektit të gegërishtes. E gjithë vepra dëshmon pozicionin humanist e demokratik të autorit e përkthyesit që e ka zgjedhur e përshtatur këtë novelë në dramë.

\section{Tematika e teatrit: dramë}

\begin{tabular}{|l|l|l|}
\hline $\mathrm{Nr}$ & Emri i dramës & I mjeri djalë! 1935 \\
\hline & \multicolumn{2}{|c|}{ SHOQËNIA E STUDENTAVET "ALBANIA" NË WIEN } \\
\hline 1 & \multicolumn{2}{|c|}{ Dramë e përkthyer me tri pamje nga Mustafa Curri. Shoqënia "Afërdita" } \\
\hline 2 & Dramaturg & Namik Qemali \\
\hline 3 & Regjizor & Thanas Floqi \\
\hline 4 & Muzika & Thanas Floqi me bandën muzikore "Afërdita" \\
\hline 5 & Skenograf + piktor & Mustafa Curri. \\
\hline
\end{tabular}

\begin{tabular}{|l|l|l|l|}
\hline $\mathrm{Nr}$ & Personazhet & & Aktori që interpreton \\
\hline 1 & Zeqi Beu - & $\begin{array}{l}\text { djalë 19 vjeç, student ne shkollën } \\
\text { mjekse të ushtris }\end{array}$ & Etëhem Haxhiademi. \\
\hline 2 & Shefikaja - & një vajzë 14 vjeç, e dashura e Zeqi Beut & Hasan Ceka. \\
\hline 3 & Halili - & I ati i Shefikas & Raku Buda \\
\hline 4 & Tahireja - & e ëma e Shefikas & Vasil Andoni \\
\hline 5 & Sherifeja - & një grue, komshije e Shefikas & Petër Andoni \\
\hline 6 & Xhemilja - & shërbëtore & Mihal Buda \\
\hline 7 & Mjeku & & Mustafa Sheshaj. \\
\hline
\end{tabular}




\section{Bibliografi}

1. Bardhyl Ajazi, "Elbasan i bukur Elbasan”.

2. Faik Pajuni "Vjet Shkolla Pedagogjike"

3. "Vatër e rëndësishme për edukimin komunist të masave", me rastin e 35-vjetorit të krijimit të shtëpisë së kulturës dhe krijimtarisë popullore, Dhjetor 1980

4. Gazeta "Posta e Shqypnis", E shtunë 3 gusht 1918, 26 korrik 1918.

5. Gazeta "Vllazënija" shtator 1918, nr. 109. fq.2

6. Sul Dedej, "Historiku i Teatrit Elbasanas"

7. Kopështi letrar, Elbasan, vjesht' e parë, 1918, nr.2.

8. Gazeta "Shkodra", nr.10

9. Pranvera Curri (Bardhi), Monografi për Mustafa Currin - Dorëshkrim personal 